\title{
LAW ENFORCEMENT AGAINST ILLEGAL FISHING IN NATUNA WATERS DURING THE COVID-19 PANDEMIC
}

\author{
Ida Kurnia \\ Fakultas Hukum Universitas Tarumanagara \\ idah@fh.untar.ac.id
}

Naskah diterima untuk diterbitkan : 30 Juli 2021

DOI : $10.34010 /$ rnlj.v\%vi\%i.5273

\begin{abstract}
Law enforcement against illegal fishing in Natuna Waters during the Covid-19 pandemic is very important, especially considering frequent illegal fishing cases during the pandemic. Therefore, it is necessary to conduct an analysis of the efforts that have been made by the Indonesian Government to solve the illegal fishing cases that have occurred in Indonesia, regarding to the protection of fishermen, especially in Natuna Waters. The purpose of this study is to determine the role of the government regarding the form of law enforcement that have been carried out, utilizing various existing government policies and regulations, as well as the implementation of these regulations in the field, both in preventive, responsive and repressive efforts, in regards to illegal fishing cases in Natuna Waters. To study this, it is necessary to analyze various juridical reviews of the rights and obligations of the Indonesian State in Indonesian waters, data on the number of illegal fishing cases in Indonesia and in the Natuna region, and general analysis of illegal fishing cases. Furthermore, it should also include the type of facilities and infrastructure that must be strengthened. Using the method of normative legal analysis, we found several weaknessesin the legal norms..
\end{abstract}

Keywords: Illegal Fishing, Government Efforts, Pandemic

\section{PENDAHULUAN}

Indonesia merupakan Negara Kepulauan (Archipelago State) yang secara geografis terdiri dari beberapa pulau yang terurai dari Sabang sampai Merauke, dari pulau Miangas sampai pulau Rote dan tetap membentuk satu kesatuan, yaitu Negara Kepulauan Indonesia. Disamping itu, Indonesia terletak di antara dua samudera, yaitu Samudera Hindia dan Samudera Pasifik, telah menunjukkan bahwa letak Indonesia pada posisi demikian membawa keuntungan tersendiri bagi Indonesia. Berdasarkan hasil dari berbagai penelitian yang telah dilakukan menunjukkan bahwa di perairan Indonesia memiliki potensi sumber daya alam hayati dan non hayati yang sangat melimpah. Oleh karena itu, Bangsa Indonesia harus bersyukur kepada Tuhan Yang Maha Esa atas anugerah Nya.

Potensi kekayaan alam yang melimpah harus dijaga, yaitu dengan mengupayakan tindakan konservasi dan memperhatikan aspek pelestarian kekayaan alam tersebut serta mempergunakan potensi kekayaan alam tersebut secara bijaksana untuk memenuhi kebutuhan dan kepentingan Bangsa Indonesia. Hal ini sesuai dengan Amanat Konstitusi, yang diatur di dalam Pasal 33 ayat (3) UUD 1945, yang mengatakan bahwa "Bumi dan air dan kekayaan alam yang terkandung di dalamnya dikuasai oleh negara dan dipergunakan untuk sebasar-besarnya kemakmuran rakyat".

Wilayah laut Indonesia yang luas dan kaya akan jenis-jenis sumber daya non hayati dan hayati termasuk potensi perikanan menunjukkan jumlah penangkapan ikan sebesar 6,4 juta ton/ tahun dan potensi perikanan umum sebesar 305.650 ton/ tahun serta potensi kelautan kurang lebih 4 miliar USD/ tahun. Sektor perikanan yang memiliki potensi yang "berlimpah" tersebut mengundang banyak nelayan asing maupun lokal melakukan kegiatan pemanfaatan sumber daya perikanan di 
Vol. 3 No. 2 Juli 2021

perairan Indonesia. ${ }^{1}$ Kondisi demikian menjadikan pemerintah Indonesia untuk mengupayakan secara terus-menerus menjaga dan melestarikan kuantitas dan kualitas termasuk keanekaragaman sumber daya hayati dan non hayati yang terkandung dalam perairan Indonesia.

Wilayah Perairan Indonesia yang termasuk ke dalam kedaulatan negara yang terbagi atas beberapa rezim hukum laut berdasarkan ketentuan hukum laut internasional, yang diatur dalam United Nations Convention on The Law of The Sea 1982 (UNCLOS 1982) telah diratifikasi oleh Indonesia dengan Undang-Undang No.17 Tahun 1985 Tentang Pengesahan UNCLOS Tahun 1982, yaitu Perairan Pedalaman, Perairan Kepulauan, Laut Teritorial, Zona Tambahan, Zona Ekonomi Eksklusif, Landas Kontinen, Laut Lepas dan Dasar Laut Dalam dan Tanah di Bawahnya. Dalam pembagian zona maritim tersebut, tiga zona pertama masuk ke dalam wilayah kedaulatan. Selanjutnya, tiga zona berikutnya terletak pada wilayah yurisdiksi, artinya Negara Pantai (dalam hal ini Negara Indonesia sebagai Negara Kepulauan) mempunyai hak untuk menguasai sumber daya alam hayati dan non hayati yang terkandung di dalamnya dan Kapal Negara Asing tidak diperbolehkan untuk mengambil sumber daya tersebut. Dua zona terakhir berada di luar wilayah kedaulatan dan di luar wilayah yurisdiksi, yang merupakan milik bersama masyarakat internasional.

Kasus ilegal fishing sering terjadi di Zona Ekonomi Eksklusif Indonesia terutama di wilayah Natuna, di Provinsi Kepulauan Riau. Daerah Natuna berbentuk kabupaten yang terletak pada koordinat :01018'00-060 50'15 Lintang Utara dan 104048'30' -11002'00" Bujur Timur. dengan luas wilayah sekitar 224.684,59 Km2. Wilayah Kabupaten Natuna memiliki luas lautan sebesar $99,11 \%$ atau $222.683,39 \mathrm{~km} 2$ dan $0.89 \%$ atau $2.001,30 \mathrm{~km} 2$ untuk, luas daratannya (BPS Kabupaten Natuna, 2017). ${ }^{2}$ Kabupaten Natuna memiliki 15 kecamatan. Kecamatan tersebut tersebar pada dua gugus pulau, yaitu: ${ }^{3}$

1. Gugus Pulau Natuna, yang terdiri dari pulau-pulau di Bunguran, Sedanau, Midai, Pulau Laut dan Pulau Tiga.

2. Gugus Pulau Serasan, yang terdiri atas pulau-pulau di Serasan, Subi Besar dan Subi Kecil.

Perairan Kepulauan Natuna berbatasan dengan Negara tetangga seperti Singapura, Malaysia, Vietnam, dan China, sehingga membuat terjadinya titik simpul pelayaran internasional yang menghubungkan Hongkong, Jepang, Korea Selatan, Taiwan dengan negara-negara lainnya. Perairan Kepulauan Natuna juga menyimpan potensi sumber daya perikanan yang besar yang mencapai 504.000 ton per tahun, Selain itu, Natuna memiliki beberapa candangan minyak bumi dengan perkiraan sebesar 36 juta barel dan total produksinya sebesar 25.000 barel per hari dan gas bumi yang terbukti sebesar 46 triliun standar kaki kubik dengan total produksi sebesar 490 juta standar kaki kubik per hari yang tersimpan di dalam Zona Ekonomi Eksklusif Indonesia yang bersinggungan dengan 9-Dash-Line ${ }^{4}$. Hal tersebut yang menyebabkan terjadinya ilegal fishing yang dilakukan oleh negara asing, sehingga pemanfaatan potensi kekayaan alam di Perairan Kepulauan Natuna di Provinsi Kepulauan Riau tidak maksimal dimanfaatkan oleh nelayan di Kepulauan Natuna. Selama ini di kepulauan Natuna nelayan asing sering memasuki dan melakukan penangkapan ikan secara ilegal, yaitu di wilayah perairan Natuna yang merupakan Zona Ekonomi Eksklusif Indonesia.

Kondisi yang terjadi seperti telah disampaikan di atas, oleh para nelayan lokal Kepulauan Natuna telah berusaha untuk menegur dan mengusir nelayan asing tersebut agar keluar dari wilayah Natuna, namun hal ini tidak menjadi perhatian mereka. Sebagai salah satu contoh kasus yang terjadi baru-baru ini pada masa pandemic covid-19 yang melanda Indonesia yang dikutip dari Artikel Detik News.Com dengan judul 2 Kapal Asing Ilegal Vietnam ditangkap di Laut Natuna Utara. Hal ini berakibat pada nelayan lokal kesulitan untuk mendapatkan ikan di Perairan Natuna.

\footnotetext{
${ }^{1}$ Marlina dan Faisal, Aspek Hukum Peran Masyarakat dalam Mencegah Tindak Pidana Perikanan (Jakarta: Sofmedia, 2013), 2.

2 Zulham Armen, dkk, Rekomendasi Pengembangan Perikanan Tangkap di Natuna dan Sekitarnya (Jakarta: PT Raja Grafindo Persada, 2017), 1.

${ }^{3}$ Ibid,. 1.

${ }^{4}$ Hasan, Syarief. "Seminar Tentang Sikap Politik Indonesia Terhadap Laut Cina Selatan" (Webinar Asosiasi Dewan Profesor Indonesia, Jakarta, 2020), 7.
} 
Fakultas Hukum Universitas Komputer Indonesia

Vol. 3 No. 2 Juli 2021

Berdasarkan pada paparan di atas, penulisan ini bertujuan untuk meninjau dan memberikan informasi tentang peranan Pemerintah Indonesia dalam melakukan Penegakan Hukum terhadap kegiatan ilegal fishing di Perairan Natuna pada masa Pandemi Covid-19. Bagaimana Peranan Pemerintah Indonesia dalam melakukan penegakan hukum terhadap ilegal fishing di Perairan Natuna di masa Pandemi Covid-19?

\section{METODE PENELITIAN}

\section{Jenis Penelitian dan Teknik Pengumpulan Data.}

Penelitian ini menggunakan penelitian normatif dengan melakukan pendekatan undangundang yaitu Undang-Undang Nomor 17 Tahun 1985 Tentang Pengesahan UNCLOS Tahun 1982, Undang-Undang No.45 Tahun 2009 Perubahan Atas Undang-Undang No.31 Tahun 2004 Tentang Perikanan, dan Undang-Undang No.5 Tahun 1983 Tentang Zona Ekonomi Eksklusif Indonesia. Ketiga undang-undang ini memiliki tujuan yang sama dalam melakukan Penegakan Hukum terhadap Kegiatan Ilegal Fishing di Perairan Indonesia. Dalam penelitian ini menjelaskan ketiga undangundang di atas untuk melihat regulasi dan kebijakan pemerintah dalam menanggulangi kegiatan ilegal fishing. Penelitian ini mengunakan data sekunder yang terdiri dari Peraturan Perundangundangan, buku-buku dan jurnal yang berkaitan dengan penegakan hukum terhadap kegiatan Ilegal Fishing serta data jumlah kasus ilegal fishing yang terjadi di Indonesia. Data yang telah terkumpul dianalisis secara kualitatif, dengan cara menganalisis secara mendalam dan menyeluruh, baik dari segi peraturannya serta budaya hukum masyarakat terkait penerapannya.

\section{Lokasi dan Waktu Penelitian.}

Studi kepustakaan dilakukan di Jakarta melalui penelusuran informasi dan pengumpulan data tertulis yang diperoleh melalui peraturan perundang-undangan, buku-buku, jurnal ilmiah dan melalui berita/artikel surat kabar, juga media internet. Lokasi kajian difokuskan di perairan WPP 711 khususnya sekitar Zona Ekonomi Eksklusif. Batasan area kajian ini didasari bahwa Zona Ekonomi Eksklusif-WPP 711 merupakan titik rawan terjadinya illegal fishing mengingat Zona Ekonomi Eksklusif tersebut merupakan perairan perbatasan dengan beberapa negara tetangga seperti Malaysia, Singapura, Vietnam dan China.

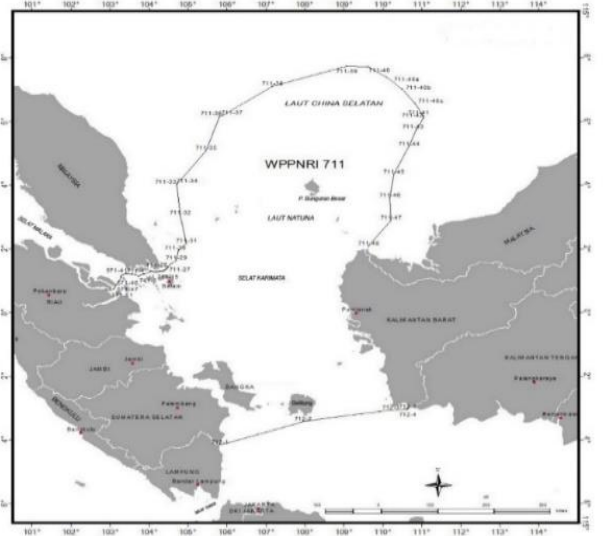

Gambar 1. Illustrasi Perairan Natuna yang terjadi Ilegal Fishing terdapat di WPPRI-711 yang meliputi perairan Selat Karimata, Laut Natuna, dan Laut China Selatan. ${ }^{5}$

\section{PEMBAHASAN}

\section{A. Hasil Penegakan Hukum Terhadap Ilegal Fishing di Perairan Natuna di Masa Pandemi}

\section{Covid-19}

Kasus ilegal fishing sampai sekarang belum terselesaikan disebabkan karena belum maksimalnya upaya yang dilakukan oleh Indonesia dalam menangani masalah ilegal fishing di ZEE

\footnotetext{
${ }^{5}$ Peraturan Menteri Kelautan dan Perikanan Nomor PER/01/MEN/2009 tentang Wilayah Pengelolaan Perikanan Republik Indonesia.
} 
Fakultas Hukum Universitas Komputer Indonesia

Vol. 3 No. 2 Juli 2021

Indonesia. Pengawasan di seluruh perairan Indonesia yang dilakukan oleh pemerintah masih terdapat kekurangan dalam hal kapal pengawas, juga jumlah hari operasi. Menurut Direktur Jenderal Pengawasan Sumber Daya Kelautan dan Perikanan bahwa keterbatasan inilah yang harus segera dicarikan solusi agar pengawasan di perairan Indonesia yang luas ini dapat berjalan optimal. Memanfaatkan nelayan sebagai human intelligence atau sumber informasi aktivitas ilegal fishing telah lama diterapkan oleh aparat pengawas di lapangan, akan tetapi terdapat beberapa kendala dimana mayoritas daerah operasi kapal ikan nelayan Indonesia masih berada jauh dari ZEEI sehingga untuk pengawasan di perairan terluar Indonesia masih dibutuhkan solusi lain agar dapat menjangkau daerah tersebut. ${ }^{6}$ Dalam penegakan hukum terhadap ilegal fishing di Perairan Natuna di Masa Pandemi Covid -19 terus dilakukan seperti dalam kasus yang dikutip dari artikel detik.com yang menyatakan bahwa terdapat 2 Kapal Ilegal Fishing dari Vietnam, dengan nama KG 93811 TS dan KG 93012 TS ditangkap oleh Kapal Pengawas Perikanan Orca 03 yang dinahkodai oleh Capt. Mohammad Ma'ruf pada posisi koordinat $03^{\circ}$ 51,172' Lintang Utara - 104 44,515' Bujur Timur.

Bersama dua kapal ikan asing ilegal yang mengoperasikan alat penangkapan ikan trawl tersebut turut diamankan 22 awak kapal berkewarganegaraan Vietnam. "Saat ini kedua kapal tersebut sedang dalam proses dikawal menuju Satwas SDKP Natuna untuk menjalani proses hukum lebih lanjut," ungkap Eddy Prabowo. Penangkapan ini, kata Edhy merupakan pesan tegas yang dikirimkan oleh KKP terhadap para pelaku ilegal fishing di perairan Indonesia. Dia memastikan, jajaran Pengawas Perikanan Ditjen PSDKP akan tetap melaksanakan upaya menjaga kedaulatan pengelolaan perikanan dari ancaman para pelaku illegal fishing. "Ini tentu bukti bahwa kami tidak lengah di tengah kondisi kita yang masih menghadapi pandemi COVID-19 ini. Dengan tetap menjalankan protokol pencegahan dan penanggulangan COVID-19, Pengawas Perikanan kami akan tetap bekerja untuk menjaga perairan kita dari para pencuri ikan agar para nelayan kita dapat melakukan kegiatan penangkapan di laut dengan aman dan nyaman," tegasnya.

Penangkapan 2 KIA ilegal berbendera Vietnam ini, menambah daftar kapal-kapal ikan asing ilegal yang sudah ditangkap di era kepemimpinan Edhy Prabowo. Total sudah 19 KIA yang telah ditangkap terdiri dari 10 kapal berbendera Vietnam, 4 kapal berbendera Filipina dan 5 kapal berbendera Malaysia. Selain penangkapan kapal ikan asing ilegal, Edhy juga telah melakukan serangkaian langkah strategis di antaranya melalui upaya pengawalan terhadap nelayan Indonesia yang beroperasi di Laut Natuna Utara dan pembebasan nelayan Indonesia yang ditangkap oleh aparat Malaysia. "Nelayan kita masih tetap perlu melaut untuk memenuhi kebutuhan hidup di masa sulit ini. Oleh sebab itu KKP hadir untuk melindungi masyarakat kelautan dan perikanan. Kami tekankan bahwa dalam kondisi apapun kami tetap komit mengawal dan melindungi nelayan Indonesia, termasuk memberantas kapal asing pelaku illegal," pungkasnya. ${ }^{7}$ Berdasarkan dari kasus tersebut penulis kemudian mengumpulkan beberapa data kasus ilegal fishing yang berhasil ditangkap di perairan Indonesia yang dapat dilihat pada tabel 1 berikut ini:

Tabel 1.

Data Kasus Ilegal Fishing di Indonesia (2014-Juni 2019)

\begin{tabular}{|l|l|l|}
\hline No & Waktu & Ilegal Fishing \\
\hline 1. & 2014 & 38 kasus \\
\hline 2. & 2015 & 102 kasus \\
\hline 3. & 2016 & 163 kasus \\
\hline
\end{tabular}

${ }^{6}$ Dendy Mahabror dan Jenjen Jenhar Hidayat. “Analisis Kerugian Ekonomi Akibat Ilegal Fishing di Zona Ekonomi Eksklusif Perairan Natuna" (Seminar Nasional Kelautan dan Perikanan V, Surabaya, 2018), 265.

${ }^{7}$ Faidah Umu Sofuroh. "2 Kapal Asing Ilegal Vietnam Ditangkap di Laut Natuna Utara." DetikNews.com. https://news.detik.com/berita/d-4965402/2-kapal-asing-ilegal-vietnam-ditangkap-di-laut-natuna-utara. (accessed April 4, 2020). 
Fakultas Hukum Universitas Komputer Indonesia

Vol. 3 No. 2 Juli 2021

\begin{tabular}{|l|l|l|}
\hline 4. & 2017 & 132 kasus \\
\hline 5. & 2018 & 109 kasus \\
\hline 6. & Juni 2019 & 38 kasus \\
\hline
\end{tabular}

Tabel 1. Data Penangkapan Kapal yang Melakukan Ilegal Fishing di Indonesia dari Tahun 2014-Juni 2019. ${ }^{8}$

Berdasarkan data yang ditunjukkan dalam tabel 1 dapat diketahui bahwa terjadi tren kenaikan kasus ilegal fishing di Perairan Kepulauan Negara Kesatuan Republik Indonesia dari Tahun 20142016 sebesar 125 kapal ilegal fishing dari sebelumnya pada tahun 2014 terjadi 38 kapal dan di tahun 2015 terjadi 102 kasus kapal serta pada tahun 2016 yang menjadi puncaknya ditemukan 163 kapal ilegal fishing di Perairan Indonesia. Walaupun pada tahun 2014-2016 terjadi tren kenaikan yang cukup signifikan akan tetapi pada tahun 2017-Juni 2019 terjadi tren penurunan jumlah kapal yang melakukan ilegal fishing.

Berdasarkan penjelasan di atas hal tersebut bisa terwujud dari peran serta pemerintah yang mengatasi dan membentuk satgas 115 yang terdiri dari beberapa lembaga penegak hukum seperti Kementerian Kelautan dan Perikanan, Badan Keamanan Laut (Bakamla), TNI Angkatan Laut dan peran serta aktif masyarakat yang melaporkan setiap adanya kapal asing masuk ke wilayah perairan Indonesia dan mengambil sumber daya hayati dan non hayati di Perairan Indonesia.

Pada saat ini Indonesia dan negara-negara di dunia sedang berusaha mengatasi pandemi covid19, sehingga penegakan hukum terhadap kapal ilegal fishing di masa pandemi menjadi lemah dan membuat para pelaku ilegal fishing semakin bertambah banyak. Berdasarkan informasi tersebut, ditindak lanjuti penulis dengan mengumpulkan data, kemudian didapat data dan disajikan dalam tabel 2 dengan judul Kapal Ilegal Fishing di Indonesia (Januari-12 Juni 2020) sebagai berikut:

Tabel 2.

Kasus Ilegal Fishing di Indonesia (Periode Januari-12 Juni 2020)

\begin{tabular}{|c|l|l|}
\hline No & Wilayah & Kasus \\
\hline 1. & WPPRI $571 \& 711$ & $\begin{array}{l}25 \text { Unit Kapal Ilegal Fishing } \\
(16+9 \text { Kapal Berbendera Malaysia) }\end{array}$ \\
\hline 2. & WPPRI 712 & 14 Unit Kapal Berbendera Indonesia \\
\hline 3. & WPPRI 716 & $\begin{array}{l}10 \text { Unit Kapal } \\
(9 \text { Kapal Bebendera Filipina dan } 1 \\
\text { Berbendera Taiwan })\end{array}$ \\
\hline
\end{tabular}

Tabel 2. Kapal Ilegal Fishing yang berhasil ditangkap periode Januari-12 Juni $2020^{9}$

Berdasarkan data yang ditunjukkan di atas jumlah kapal ilegal fishing berhasil ditangkap dan dilakukan Penegakan Hukum sebanyak 49 unit kapal ilegal fishing yang tersebar dari wilayah WPPRI 571, WPPRI 711, WPPRI 712, WPPRI 716. Data menunjukkan bahwa kapal berbendera

\footnotetext{
8 Data di atas berdasarkan intisari Penulis yang diambil dari beberapa sumber: 1. Lily Aprilya Pregiwati."Kinerja Pengawasan KKP Sepanjang Triwulan 1/2019 Tunjukkan Capaian Positif." (Website kkp.go.id. 11 April 2019) https://kkp.go.id/artikel/10031-kinerja-pengawasan-kkp-sepanjang-triwulan-12019-tunjukkan-capaian-positif/diakses/8/10/2020 (accessed October 8, 2020). 2. Bayu Legianto. "Hasil Operasi Kapal Pengawas Perikanan KKP.” (Website suarakarya.co.id, Juli 2019) https://suarakarya.co.id/kinerja-pemerintah-kkp-tangkap-67-kapal-pencuri-ikan/15703/diakses/8/10/2020 (accessed October 8, 2020).

9 Pung Nugroho Saksono. "Upaya Indonesia Memerangi IUU Fishing” (Webinar Situasi Keamanan Laut China Selatan di Tengah Pandemi Covid-19 Dalam Perspektif Politik Hukum Internasional serta Sikap Indonesia, Jakarta, 2020), 14.
} 
Fakultas Hukum Universitas Komputer Indonesia

Vol. 3 No. 2 Juli 2021

negara Vietnam dan Malaysia banyak melakukan kegiatan ilegal fishing sebanyak 16 unit kapal ilegal fishing dan 9 Unit Kapal Ilegal Fishing Berbendera Malaysia yang beroperasi di wilayah WPPRI 571 meliputi Perairan Selat Malaka dan Laut Andaman \& WPPRI 711 yang meliputi Perairan Selat Karimata, Laut Natuna, China Selatan) dengan total keseluruhannya 25 Unit Kapal ilegal fishing yang berhasil ditangkap pada WPPRI $571 \& 711$.

Pada posisi kedua dari Kapal berbendera Indonesia yang melakukan kegiatan ilegal fishing sebanyak 14 unit kapal yang melakukan ilegal fishing di wilayah WPPRI 712 yang meliputi Perairan Laut Jawa. Pada Posisi ketiga kapal ilegal fishing yang berbendera Filipina dan Taiwan beroperasi di wilayah WPPRI 716 yang meliputi perairan Laut Sulawesi dan sebelah Utara Pulau Halmahera sebanyak 9 unit kapal berbendera Filipina dan 1 unit kapal berbendera Taiwan, dengan total keseluruhannya sebanyak 10 unit kapal ilegal fishing yang berhasil di tangkap pada WPPRI 716. Berdasarkan pada data di atas penulis menemukan data yang lebih spesifik mengenai kasus ilegal fishing yang terjadi di Indonesia dengan meliputi 4 WPPRI yaitu: WPPRI 571, 711,712,716 yang terjadi pada periode Maret-April 2020 dan disajikan dalam:

Tabel 3.

Kapal Ilegal Fishing yang berhasil ditangkap Periode Maret-April 2020

\begin{tabular}{|c|c|c|}
\hline No & Wilayah & Kasus \\
\hline 1. & WPPRI 571 & 7 \\
\hline 2. & WPPRI 711 12 \\
\hline 3. & WPPRI 712 & 4 \\
\hline 4. & WPPRI 716 & 5 \\
\hline
\end{tabular}

Tabel 3. Kapal Ilegal Fishing yang berhasil ditangkap Periode Maret-April $2020^{10}$

Berdasarkan data yang ditunjukkan di atas dapat diketahui bahwa jumlah kapal yang melakukan ilegal fishing pada Periode Maret-April 2020 dengan total keseluruhan sebanyak 28 kasus ilegal fishing yang tersebar di WPPRI 571, 711, 712, 716. Pada WPPRI 571, data menunjukkan bahwa kapal berbendera Negara Malaysia melakukan kegiatan ilegal fishing sebanyak 7 yang berada di Selat Malaka (yang termasuk ke dalam WPPRI 571), meliputi Perairan Selat Malaka dan Laut Andaman. Kemudian WPPRI 711, data menunjukkan bahwa kapal berbendera Negara Vietnam melakukan kegiatan ilegal fishing sebanyak 12, yang beroperasi pada laut natuna (yang termasuk ke dalam WPPRI 711), meliputi Perairan Selat Karimata, Laut Natuna, China Selatan.

Selanjutnya, pada WPPRI 712 data menunjukkan bahwa kapal berbendera Negara Indonesia melakukan kegiatan ilegal fishing sebanyak 4 pada Laut Jawa (yang termasuk ke dalam WPPRI 712), meliputi Perairan Laut Jawa. Kemudian, pada WPPRI 716, data menunjukkan bahwa kapal berbendera Negara Filipina dan Taiwan melakukan kegiatan ilegal fishing sebanyak 4 kapal berbendera Negara Filipina dan 1 kapal berbendera Negara Taiwan, jumlah sebanyak 5 kapal yang melakukan ilegal fishing di Laut Sulawesi (yang termasuk ke dalam WPPRI 716), meliputi perairan Laut Sulawesi dan sebelah utara Pulau Halmahera. Berdasarkan data di atas menunjukkan jumlah kapal yang melakukan ilegal fishing yang terbanyak adalah kapal berbendera Negara Vietnam yang beroperasi di WPPRI 711 yang meliputi Perairan Selat Karimata, Laut Natuna, Laut China Selatan. Artinya ilegal fishing yang terbanyak pada saat pandemi covid 19 di wilayah Laut Natuna.

${ }^{10}$ Berdasarkan intisari Penulis yang diambil dari beberapa sumber: 1. Sherief Maronie dan Rangga Dwi Wahyuputra. "Penanganan Tindak Pidana Perikanan Oleh PPNS Perikanan di Masa Pandemi Covid-19." KKP.go.id, Jakarta: KKP https://kkp.go.id/djpsdkp/artikel/19429-penanganan-tindak-pidana-perikanan-olehppns-perikanan-di-masa-pandemi-covid-19, (accessed May 12,2020). 2. Peraturan Menteri Kelautan dan Perikanan Nomor PER/01/MEN/2009 tentang Wilayah Pengelolaan Perikanan Republik Indonesia. 
Fakultas Hukum Universitas Komputer Indonesia

Vol. 3 No. 2 Juli 2021

Lebih lanjut penulis melakukan kajian dalam rangka memastikan bahwa pada saat terjadi pandemi covid 19 terjadi kenaikan ilegal fishing yang cukup signifikan di Laut Natuna dan penulis memperoleh data yang menunjukkan adanya penambahan jumlah kasus ilegal fishing yang terjadi di Laut Natuna Utara periode Januari-Agustus tahun 2020, berikut akan dijelaskan data tersebut.

Tabel 4.

Kapal Ilegal Fishing di Laut Natuna Utara Periode Januari-Agustus 2020

\begin{tabular}{|c|c|c|}
\hline No & Waktu & Kasus \\
\hline 1. & Januari & 0 \\
\hline 2. & Februari & 0 \\
\hline 3. & Maret & 5 \\
\hline 4. & April & 7 \\
\hline 5. & Mei & 2 \\
\hline 6. & Juni & 2 \\
\hline 7. & Juli & 2 \\
\hline 8. & Agustus & 5 \\
\hline
\end{tabular}

Tabel 4. Kapal Ilegal Fishing di Laut Natuna Utara Periode Januari-Agustus $2020^{11}$

Berdasarkan data di atas, pada Bulan Januari sampai dengan Bulan Februari tahun 2020 di Laut Natuna Utara yang termasuk ke dalam WPPRI-711 yang meliputi Perairan Selat Karimata, Laut Natuna dan Laut China Selatan tidak ditemukan kapal yang berbendera Negara Vietnam melakukan ilegal fishing. Artinya sebelum di Indonesia terjadi pandemi covid 19 kapal yang berbendera Negara Vietnam tidak melakukan ilegal fishing di WPPRI-711. Namun ketika Bulan Maret tahun 2020 yang merupakan bulan dimana di Negara Indonesia mulai terjadi pandemik covid-19, di Laut Natuna Utara ditemukan 5 kapal berbendera Negara Vietnam melakukan kegiatan ilegal fishing.

Pada bulan-bulan berikutnya, yaitu mulai Bulan April hingga Bulan Agustus secara terusmenerus terjadi ilegal fishing yang dilakukan kapal yang berbendera Negara Vietnam, bahkan pada Bulan April jumlah kapal yang melakukan ilegal fishing mengalami peningkatan yang cukup signifikan mencapai 28,57 persen, yaitu ditemukan 7 kapal yang melakukan ilegal fishing di Laut Natuna Utara. Pada Bulan Mei hingga Bulan Juli juga masih ditemukan kasus ilegal fishing. Pada 3 bulan tersebut masing-masing terdapat 2 kapal berbendera Negara Vietnam yang melakukan kegiatan ilegal fishing. Setelah itu pada Bulan Agustus terdapat kenaikan lagi, yaitu ada 5 kapal yang melakukan ilegal fishing. Berdasarkan data di atas, maka pada periode Bulan Januari hingga Bulan Agustus tahun 2020 terjadi ilegal fishing di Laut Natuna Utara sebanyak 23 kapal dan semua dilakukan oleh kapal yang berbendera Negara Vietnam.

\footnotetext{
${ }^{11}$ Pung Nugroho Saksono. "Tantangan Pengawasan Perikanan di Perbatasan.” (Webinar Penengakan Hukum di Perairan Perbatasan, Jakarta, 2020), 12. https://www.youtube.com/watch?v=e1bgSyVTL0/diakses/8/10/2020.
} 
Vol. 3 No. 2 Juli 2021

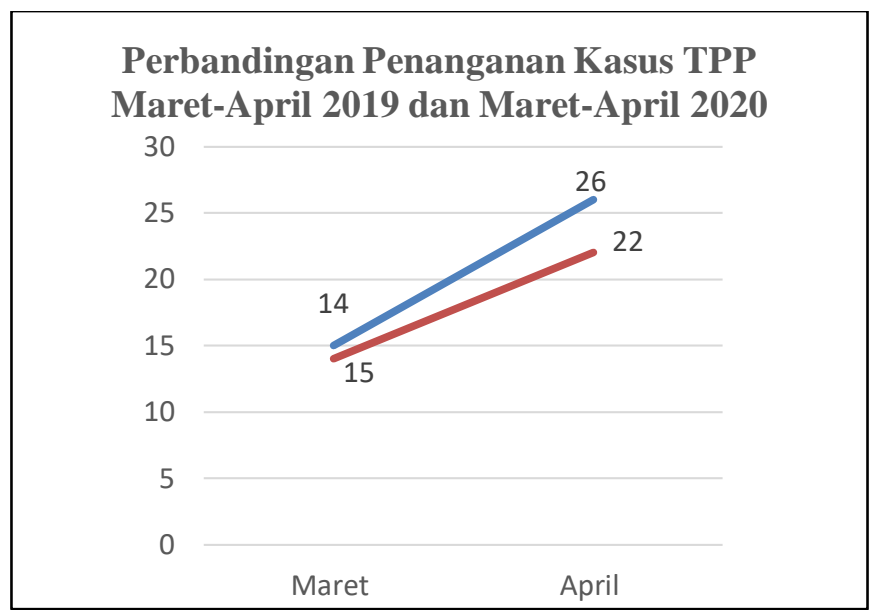

Grafik 1. Perbandingan Penanganan Kasus TPP Maret-April 2019 dan $2020^{12}$

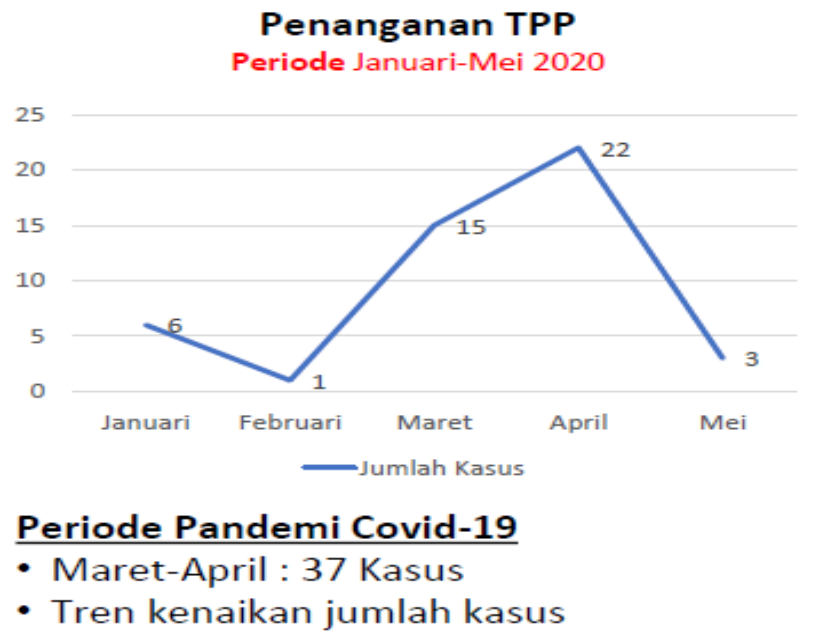

\section{Grafik 2. Penanganan TPP Periode Januari-Mei $2020^{13}$}

Berdasarkan data grafik 1 dari tahun 2014-2019 terjadi tren penurunan pada tahun 2019. Tapi jumlah ini berbanding terbalik dengan tindak pidana perikanan yang terjadi selama covid 19 yang dapat ditunjukan melalui grafik 1 yang terjadi tren kenaikan kasus tindak pidana perikanan. Berdasarkan kesimpulan grafik 1 dan grafik 2, maka pada periode Januari-Februari 2020 sebelum virus covid-19 ditetapkan sebagai pandemi ada 7 kasus, kemudian di Bulan Maret 15 kasus yang selanjutnya pada Bulan April naik menjadi 22 kasus, dengan total kasus selama masa pandemi di Bulan Maret dan April ada 37 kasus, dapat disimpulkan secara persentase di tahun 2020 kasus tindak pidana perikanan naik 428,5\% selama masa pandemi covid-19.

Penanganan tindak pidana perikanan terhadap 37 kasus merupakan hasil operasi Kapal Pengawas Perikanan sebanyak 28 kasus penangkapan kapal perikanan, dengan 6 kasus diproses secara splitsing. Sedangkan 3 kasus hasil operasi pengawasan oleh Dinas Kelautan dan Perikanan

${ }^{12}$ Grafik 1 di atas menunujukkan adanya tren penurunan tindak pidana perikanan, pada Maret-April 2019 total kasus ada 40, sedangakan pada Maret-April 2020 total kasus sebanyak 37. Secara persentase di masa pandemi Covid-19 dibandingkan masa normal di Maret-April 2019 mengalami penurunan sebesar 7,5\%. KKP. "Penanganan Tindak Pidana Perikanan oleh PPNS Perikanan di Masa Pandemi Covid-19." https://kkp.go.id/djpsdkp/artikel/19429-penanganan-tindak-pidana-perikanan-oleh-ppns-perikanan-di-masapandemi-covid-19 (accessed April 29, 2020).

${ }^{13}$ Pung Nugroho Saksono. "Tantangan Pengawasan Perikanan di Perbatasan", (Webinar Penengakan Hukum di Perairan Perbatasan, Jakarta, 2020), 14. 
Fakultas Hukum Universitas Komputer Indonesia

Vol. 3 No. 2 Juli 2021

daerah terkait penangkapan ikan dengan menggunakan bahan peledak dan bahan kimia. ${ }^{14}$ Walaupun pada grafik 1 dan grafik 2 terjadi penurunan tetapi penurunan yang dihasilkan hanya berkurang 3 kasus/tahun saja. Adanya dua perbandingan dapat menghasilkan dua kesimpulan yang berbeda, hal ini tergantung dari sudut pandang mana kita melihat angka dimaksud, jika melihat persentase penanganan kasus di tahun 2020 maka ada tren kenaikan kasus di masa pandemi covid-19 sebesar $428,5 \%$.

Ada beberapa faktor yang mempengaruhi tren peningkatan, dan apabila menyimpulkan bahwa tren peningkatan tersebut adalah disebabkan oleh masa pandemi covid-19 yang dijadikan kesempatan bagi pelaku ilegal fishing, maka hal itu perlu dilakukan penelitian dan pembuktian lebih lanjut. Tetapi, apabila melihat fenomena dan data-data yang disampaikan di atas, maka kondisi pandemi covid-19 akan berpotensi terjadi kerawanan yang dapat dimanfaatkan oleh pelaku ilegal fishing. Dengan banyaknya kapal pelaku tindak pidana perikanan yang ditangkap pada masa pendemi covid-19, berimbas kepada penanganan awak kapal pelaku tindak pidana perikanan yang penanganannya dilaksanakan di RPS. Hal ini dapat dijadikan perhatian dalam fenomena penanganan tindak pidana perikanan di masa pandemi covid-19 yaitu terkait kapasitas RPS yang belum memadai apabila diberlakukan sesuai protokol pencegahan penularan dan penyebaran covid-19. ${ }^{15}$

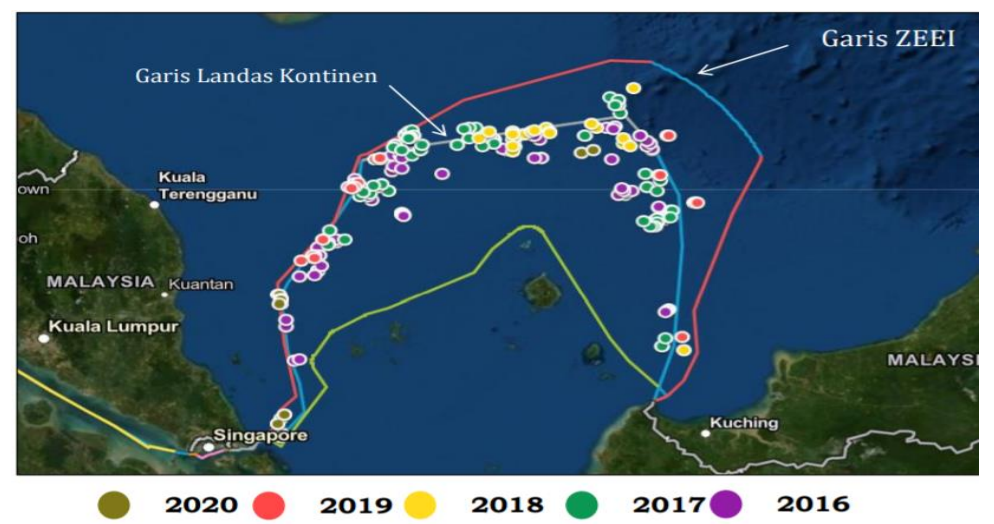

Gambar 2. KIA Berbendera Vietnam yang ditangkap KKP di wilayah WPPRI 711 pada Tahun 2016- 5 Mei $2020^{16}$

Berdasarkan gambar di atas, pada tahun 2016 terdapat peningkatan jumlah kapal yang melakukan ilegal fishing yang tersebar di WPPRI 711 yang meliputi Perairan Selat Karimata, Laut Natuna, Laut China Selatan dan terdapat di dalam Garis landas kontinen. Peningkatan jumlah kapal ilegal fishing yang berbendera Vietnam semakin banyak di tahun 2017, dapat dilihat dari titik bulat berwarna hijau dan ini dianggap sebagai puncaknya. Pada tahun 2018 jumlah kapal ilegal fishing berbendera Vietnam mengalami penurunan, dapat dilihat pada titik bulat berwarna kuning dan pada tahun 2019 hingga 5 Mei 2020 digambarkan dengan titik bulat berwarna merah juga mengalami penurunan, walaupun masih ada kapal ilegal fishing yang berbendera Vietnam tetapi jumlahnya telah menurun, hal ini ditunjukan dengan titik bulat berwarna hijau tua. Data ilegal fishing yang dilakukan oleh KIA yang berbendara Vietnam oleh Pung Nugroho Saksono dalam makalahnya yang disampaikan pada Webinar: jumlah angka, sebanyak 157 dari 214 (73.4\%) dengan posisi di dalam batas landas kontinen RI. Pada kesempatan yang sama juga disampaikan bahwa dalam penegakan hukum terhadap kapal berbendera Vietnam terdapat modus baru, yaitu: ${ }^{17}$

\footnotetext{
${ }^{14}$ Sherief Maronie dan Rangga Dwi Wahyuputra, Penanganan Tindak Pidana Perikanan Oleh PPNS Perikanan Di Masa Pandemi Covid-19, https://kkp.go.id/djpsdkp/artikel/19429-penanganan-tindak-pidana-perikananoleh-ppns-perikanan-di-masa-pandemi-covid-19, (accessed April 4, 2021). ${ }^{15}$ Ibid., 7 .

${ }^{16}$ Pung Nugroho Saksono, Op. Cit.,16.

${ }^{17}$ Ibid., 17.
} 


\section{Res Nullius}

Fakultas Hukum Universitas Komputer Indonesia

Vol. 3 No. 2 Juli 2021

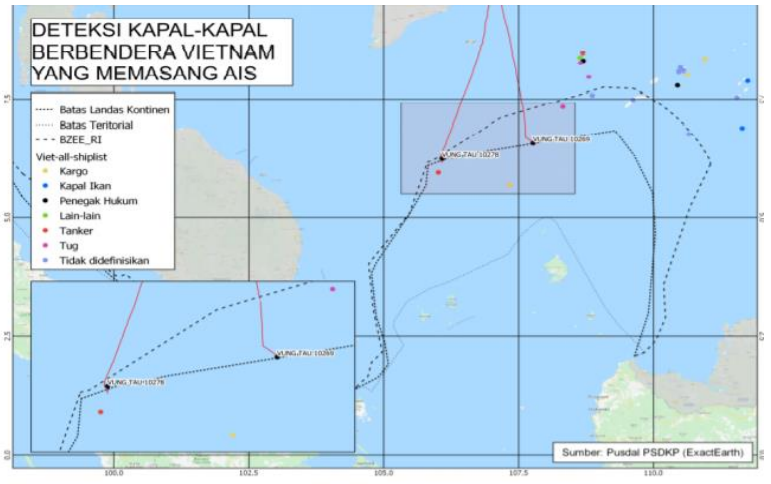

Gambar 3. Pantauan Radar tanggal 29/12/2019 Kapal Pengawas Perikanan Vietnam mengawal Kapal Ikan Vietnam

1. Peningkatan agresifitas dari Kapal Fisheries Resources Surveillance dan Kapal Coast Guard Vietnam di area Unresolved Boundary area:

a. Penempatan secara bergantian di sepanjang Batas Landas Kontinen (BLK).

b. Running Text dan Voice secara berulang-ulang (dalam Bahasa Inggris dan Indonesia) yang berisi pesan "Keluarlah dari wilayah Vietnam".

c. Mengejar Kapal Pengawas Perikanan Indonesia ketika melakukan pengejaran/ hot persuit, dimana lokasi identifikasi pelanggaran di area ZEEI.

2. KIA Vietnam menunjukkan perlawanan dan bahkan menabrakkan diri saat pengejaran (diduga karena merasa ada petugas yang "back up"). 3.

Tabel 5.

Potensi Sumber Daya Perikanan di Seluruh WPP-RI

\begin{tabular}{|r|l|r|}
\hline No & Wilayah & \multicolumn{1}{|c|}{ Jumlah Potensi } \\
\hline 1. & WPP-RI 571 & 425.444 .000 \\
\hline 2. & WPP-RI 572 & 1.240 .975 .000 \\
\hline 3. & WPP-RI 573 & 1.267 .540 .000 \\
\hline 4. & WPP-RI 711 & 767.126 .000 \\
\hline 5. & WPP-RI 712 & 1.341 .632 .000 \\
\hline 6. & WPP-RI 713 & 1.177 .857 .000 \\
\hline 7. & WPP-RI 714 & 1.242 .526 .000 \\
\hline 8. & WPP-RI 716 & 597.139 .000 \\
\hline 9. & WPP-RI 717 & 1.054 .695 .000 \\
\hline 10. & WPP-RI 718 & 2.537 .565 .000 \\
\hline
\end{tabular}

Tabel 5. Pontensi Sumber daya Perikanan di Seluruh WPP-RI Tahun $2016^{18}$

\section{B. Penegakan Hukum Terhadap Ilegal Fishing}

Berdasarkan data di atas menunjukkan bahwa secara tahunan kasus kegiatan ilegal fishing terjadi tren kenaikan, sehingga pemerintah Indonesia harus tetap waspada dan melakukan antisipasi terhadap kenaikan kasus yang ditimbulkan dari kegiatan ilegal fishing di perairan Indonesia. Sebagai bentuk antisipasi, pemerintah Indonesia telah meratifikasi UNCLOS 1982 dengan diundangkannya

\footnotetext{
${ }^{18}$ Trian Yunanda. “Arah Kebijakan Pengelolaan Sumber daya Perikanan Tahun 2020-2024.” KKP.go.id Slide 1 (kkp.go.id). (accessed April 4, 2020).
} 
Vol. 3 No. 2 Juli 2021

UU No.17 Tahun 1985 tentang Pengesahan UNCLOS Tahun 1982. ${ }^{19}$ Dengan adanya ratifikasi/ aksesi negara-negara terikat kepada UNCLOS 1982. Kegiatan ilegal fishing tidak diatur secara eksplisit di dalam UNCLOS Tahun $1982,{ }^{20}$ namun wacana tentang ilegal fishing tertera dalam kerangka IUU Fishing pada saat diselenggarakannya forum Commision for Conservation of Atlantic Marine Living Resources (CCAMLR) pada 27 Oktober -7 November $1997 .{ }^{21}$ IUU fishing dapat dikategorikan dalam tiga kelompok: ${ }^{22}$

1. Ilegal fishing yaitu kegiatan penangkapan ikan secara ilegal di perairan wilayah atau ZEE suatu negara, atau tidak memiliki izin dari negara tersebut;

2. Unregulated fishing yaitu kegiatan penangkapan di perairan wilayah atau ZEE suatu negara yang tidak mematuhi aturan yang berlaku di negara tersebut; dan

3. Unreported fishing yaitu kegiatan penangkapan ikan di perairan wilayah atau ZEE suatu negara yang tidak dilaporkan baik operasionalnya maupun data kapal dan hasil tangkapannya.

Merujuk pada pengertian ilegal fishing tersebut, secara umum dapat diidentifikasikan menjadi empat golongan yang merupakan ilegal fishing umum terjadi di Indonesia, yaitu ${ }^{23}$

1. Penangkapan ikan tanpa izin;

2. Penangkapan ikan dengan menggunakan izin palsu;

3. Penangkapan ikan dengan menggunakan alat tangkap terlarang;

4. Penangkapan ikan dengan jenis (spesies) yang tidak sesuai dengan izin.

Kegiatan ilegal fishing merupakan kejahatan dan dilarang menurut ketentuan hukum dan bagi yang melakukan serta melanggar ketentuan, maka pelakunya akan diberi sanksi karena sudah merusak lingkungan dan biota laut. Perilaku seperti ini terdapat beberapa faktor yang mempengaruhi terjadinya ilegal fishing seperti: ${ }^{24}$

1. Tingkat Konsumsi ikan semakin meningkat;

2. Sumber daya ikan di Negara Lain semakin berkurang;

3. Armada Perikanan Nasional yang lemah;

4. Adanya Keterlibatan Oknum Aparat Penegak Hukum dan Keamanan;

5. Lemahnya Penegakan Hukum di Laut Indonesia;

6. Lemahnya Pengawasan Aparat Penegak Hukum di Laut Indonesia.

Dalam prakteknya kegiatan ilegal fishing terjadi di kawasan laut yang tunduk di bawah kedaulatan dan di ZEE. Dilakukan oleh kapal berbendera negara pantai yang bersangkutan itu sendiri maupun oleh kapal berbendera asing.

Disamping telah meratifikasi UNCLOS 1982, pemerintah Indonesia juga telah menyiapkan berbagai regulasi, sebagai berikut:

${ }^{19}$ Undang-Undang Nomor 17 Tahun 1985 tentang Pengesahan United Nations Convention on the Law of the Sea 1982.

${ }^{20}$ UNCLOS 1982 mengatur tentang rezim-rezim yang ada dalam hukum laut, artinya di dalam tiap-tiap rezim mempunyai hak-hak, kewajiban-kewajiban termasuk kewenangan-kewenangan di dalamnya, khususnya di wilayah kedaulatan dan rezim ZEE, UNCLOS 1982 mengatur kewajiban-kewajiban, hak-hak dan kewenangan-kewenangan yang berkaitan dengan sumber daya alam hayati, termasuk ikan di dalamnya.

21 Rokhmin Dahuri. "Selamatkan Indonesia dari Ilegal Fishing”, Majalah Samudera, Mei 2012 http://rokhmindahuri.info/2012/10/04/selamatkan-indonesia-dari-iuu-fishing/

22 Ibid.

${ }^{23}$ Nunung Mahmuda. Ilegal Fishing-Pertanggungjawaban Pidana Korporasi di Wilayah Perairan Indonesia. (Jakarta: PT Sinar Grafika, 2015), 81.

${ }^{24}$ Halimatul Maryani dan Adawiyah Nasution. "Rekosepsi Model Pemberantasan Ilegal Fishing di Perairan Indonesia (Analisis Perspektif Hukum Internasional)", Jurnal Legislasi Indonesia, vol.16, no. 3 (September 2019): 383. https://docplayer.info/169316433-Rekonsepsi-model-pemberantasan-illegal-fishing-di-perairanindonesia-analisis-perspektif-hukum-internasional.html 
Fakultas Hukum Universitas Komputer Indonesia

Vol. 3 No. 2 Juli 2021

1. UU No.17 Tahun 1985 Tentang Pengesahan UNCLOS $1982 .{ }^{25}$

a. Dalam UU No. 17 Tahun 1985 terdapat hak dan kewajiban negara pantai atau negara kepulauan khusus untuk Zona Ekonomi Eksklusif yang terdapat hak-hak berdaulat dan yurisdiksi khusus pada Pasal 56 ayat (1) No.17 Tahun 1985, sebagai berikut:

1) Hak Negara Pantai

a) Eksplorasi dan eksploitasi sumber daya kelautan hayati dan non hayati;

b) Membuat dan memberlakukan peraturan perundang-undangan yang berkaitan dengan eksplorasi dan eksploitasi sumber daya kelautan;

c) Pembangunan pulau buatan dan instalasi permanen lainnya;

d) Mengadakan penelitian ilmiah kelautan; dan

e) Perlindungan lingkungan laut.

2) Kewajiban Negara Pantai

a) Menghormati eksistensi hak dan kewajiban negara lain atas wilayah ZEE;

b) Menentukan maximum allowable catch untuk sumber daya hayati dalam hal ini sumber daya ikan; dan

c) Dalam hal negara pantai tidak dapat mengambil total allowable catch, maka surplusnya diberikan kepada negara lain melalui perjanjian (penetuan total allowable catch dengan mempertimbangkan aspek pelestarian dan konservasi).

b. Dalam UU No.17 Tahun 1985 terdapat hak dan kewajiban negara lain di Zona Ekonomi Eksklusif. Hak negara lain di zona ekonomi eksklusif yang menyatakan "semua negara menikmati kebebasan" sesuai dengan Pasal 87 UU No.17 Tahun 1985, sedangkan kewajiban negara lain wajib memperhatikan hak dan kewajiban negara pantai dan harus mematuhi peraturan perundangundangan yang berlaku. Dengan berlakunya hal tersebut terdapat beberapa implikasi yang harus diperhatikan seperti: ${ }^{26}$

1) Zona Ekonomi Ekslusif tidak menjadi laut lepas akan tetapi kebebasan laut lepas dapat dinikmati di Zona Ekonomi Eksklusif seperti Navigasi, penerbangan, pelayaran.

2) Terbatasnya kewenangan negara dalam menegakan kedaulatan negara tidak seperti pada konsep internal waters (Perairan Pedalaman)

3) Kegiatan criminal umum yang terjadi di Zona Ekonomi Eksklusif berlaku ketentuan di laut bebas.

4) Negara Pantai harus melakukan beberapa kegiatan seperti konservasi, perlindungan lingkungan hidup di wilayah Zona Ekonomi Eksklusif, dan lain-lain.

5) Negara pantai harus mulai mengembangkan riset-riset terbaru tentang wilayah Zona Ekonomi Eksklusif dengan menggunakan konsep marine scientific research.

c. Dalam UU No.17 Tahun 1985 terdapat penegakan hukum terhadap ilegal fishing yang diatur dalam Pasal 73 yang menyatakan beberapa point penting yaitu: ${ }^{27}$

1) Negara pantai dalam melaksanakan hak berdaulatnya untuk eksplorasi, eksploitasi, konservasi \& pengelolaan sumber daya alam hayati di ZEE dapat mengambil langkah-langkah boarding, inspection, arrest dan judicial

\footnotetext{
${ }^{25}$ Undang-Undang Nomor 17 Tahun 1985 Tentang Pengesahan United Nations Convention on the Law of the Sea 1982.

${ }^{26}$ Kresna Buntoro. "Penegakan Hukum di Perbatasan Laut: Legal dan Practical Approach" (Webinar Asosiasi Profesor Indonesia, Jakarta, 2020), 12.

${ }^{27}$ Ibid., 13.
} 
proceeding, sebagai bagian dalam pentaatan perundang-undangan sesuai dengan konvensi ini;

2) Kapal yang ditangkap beserta anak buah kapal harus segera dilepaskan setelah membayar jaminan;

3) Hukuman yang dikenakan terhadap tindak pidana perikanan tidak boleh berupa "hukuman badan" kecuali ada perjanjian;

4) Dalam hal penahanan kapal asing, negara pantai harus segera memberitahukan negara bendera melalui saluran diplomatik, termasuk hukuman yang dijatuhkan.

d. Undang-Undang No.5 Tahun 1983 Tentang Zona Ekonomi Eksklusif ${ }^{28}$

a. Pemerintah Indonesia sebagai negara kepulauan menetapkan beberapa kegiatan di Zona Ekonomi Eksklusif Indonesia dengan ketentuan yang tersirat pada Pasal 5 yang menyatakan bahwa: Dengan tidak mengurangi ketentuan Pasal 4 ayat (2) menyatakan bahwa; "barang siapa melakukan eksplorasi dan/atau eksploitasi sumber daya alam atau kegiatan-kegiatan lainnya untuk eksplorasi dan/atau eksploitasi ekonomis seperti pembangkitan tenaga dari air, arus dan angin di Zona Ekonomi Eksklusif Indonesia, harus berdasarkan izin dari Pemerintah Republik Indonesia atau berdasarkan persetujuan internasional dengan Pemerintah Republik Indonesia dan dilaksanakan menurut syarat-syarat perizinan atau persetujuan internasional tersebut".

b. Atas dasar diperbolehkannya beberapa kegiatan di Zona Ekonomi Eksklusif maka diatur pula mengenai penegakan hukum, bilamana kapal negara asing Melakukan penangkapan ikan di ZEE Indonesia dengan tidak meminta izin dari Pemerintah Indonesia selaku Negara Kepulauan. Hal ini diatur dalam Pasal 13 yang menyatakan bahwa: Dalam rangka melaksanakan hak berdaulat, hak-hak lain, yurisdiksi dan kewajiban-kewajiban sebagaimana dimaksud dalam Pasal 4 ayat (1), aparatur penegak hukum Republik Indonesia yang berwenang, dapat mengambil tindakan-tindakan penegakan hukum sesuai dengan Undang-undang Nomor 8 Tahun 1981 tentang Kitab Undang-undang Hukum Acara Pidana.

c. Dalam menunjang pelaksanaan Pasal 13 mengenai penegakan hukum di Zona Ekonomi Eksklusif di Indonesia maka dibentuklah Ketentuan Pidana yang terdapat dalam Pasal 16 ayat (1) yang menyatakan bahwa: "Barangsiapa melakukan tindakan-tindakan yang bertentangan dengan ketentuan Pasal 5 ayat (1), Pasal 6, dan Pasal 7 dipidana dengan pidana denda setinggi-tingginya Rp225.000.000,- (dua ratus dua puluh lima juta rupiah)". Selanjutnya ditetapkan pula mengenai aparatur penegak hukum, penuntut umum serta pengadilan yang berwenang untuk menangani penegakan hukum mengenai IUU Fishing yang tertuang dalam Pasal 14 Undang-Undang No.5 Tahun 1983.

e. Undang-Undang No.45 Tahun 2009 tentang Perubahan Atas Undang-Undang No.31 Tahun 2004 tentang Perikanan.

Dalam hal menangani kasus Ilegal Fishing terdapat ketentuan yang diatur didalam beberapa pasal yaitu ${ }^{29}$ :

a. Pasal 69 ayat (4) menyatakan bahwa: Dalam melaksanakan fungsi sebagaimana dimaksud pada ayat $(1)^{30}$ penyidik dan/ atau pengawas perikanan dapat melakukan tindakan khusus berupa pembakaran dan/ atau

\footnotetext{
${ }^{28}$ Undang-Undang Nomor 5 Tahun 1983 tentang Zona Ekonomi Eksklusif Indonesia.

${ }^{29}$ Undang-Undang Nomor 45 Tahun 2009 tentang Perubahan Atas Undang-Undang Nomor 31 Tahun 2004 tentang Perikananan.

${ }^{30}$ Kapal pengawas perikanan berfungsi melaksanakan pengawasan dan penegakan hukum di bidang perikanan dalam Wilayah Pengelolaan Perikanan Negara Republik Indonesia.
} 
penenggelaman kapal perikanan yang berbendera asing berdasarkan bukti permulaan yang cukup.

b. Pasal 93 ayat (2) yang menyatakan bahwa: "Setiap orang yang memiliki dan/ atau mengoperasikan kapal penangkap ikan berbendera asing melakukan penangkapan ikan di ZEE Indonesia yang tidak memiliki Surat Izin Penangkapan Ikan (SIPI) sebagaimana dimaksud dalam Pasal 27 ayat (2), dipidana dengan pidana penjara paling lama 6 (enam) tahun dan denda paling banyak Rp20.000.000.000,00 (dua puluh miliar rupiah)"

c. Pasal 93 ayat $(4)^{31}$ yang menyatakan bahwa: " Setiap orang yang mengoperasikan kapal penangkap ikan berbendera asing di ZEE Indonesia, yang tidak membawa SIPI asli sebagaimana dimaksud dalam Pasal 27 ayat (3), dipidana dengan pidana penjara paling lama 6 (enam) tahun dan denda paling banyak Rp20.000.000.000,00 (dua puluh miliar rupiah)".

d. Pasal 94 A menyatakan bahwa: "Setiap orang yang memalsukan dan/ atau menggunakan Surat Izin Usaha Perikanan (SIUP), SIPI, dan Surat Izin Kapal Pengangkut Ikan (SIKPI) palsu sebagaimana dimaksud dalam Pasal 28A dipidana dengan pidana penjara paling lama 7 (tujuh) tahun dan denda paling banyak Rp3.000.000.000,00 (tiga miliar rupiah)". Dengan adanya aturan mengenai setiap kapal berbendera Indonesia dan berbendera asing wajib memiliki SIPI yang dikeluarkan oleh Kementerian Kelautan dan Perikanan Republik Indonesia maka ini merupakan suatu penegakan hukum yang dapat dilakukan oleh Pemerintah Indonesia.

e. Pasal 97 ayat $(1,2,3)$ mengatur tentang seorang nahkoda kapal yang menjalankan kapal penangkap ikan berbendera asing di wilayah pengelolaan perikanan Indonesia haruslah memiliki izin penangkapan ikan dari Pemerintah Indonesia. Berikut ini ketentuan lebih lengkap mengenai ayat tersebut yaitu:

1) Nakhoda yang mengoperasikan kapal penangkap ikan berbendera asing yang tidak memiliki izin penangkapan ikan, yang selama berada di wilayah pengelolaan perikanan Republik Indonesia tidak menyimpan alat penangkapan ikan di dalam palka sebagaimana dimaksud dalam Pasal 38 ayat (1), dipidana dengan pidana denda paling banyak Rp500.000.000,00 (lima ratus juta rupiah).

2) Nahkoda yang mengoperasikan kapal penangkap ikan berbendera asing yang telah memiliki izin penangkapan ikan dengan 1 (satu) jenis alat penangkapan ikan tertentu pada bagian tertentu di ZEE Indonesia yang membawa alat penangkapan ikan lainnya sebagaimana dimaksud dalam Pasal 38 ayat (2), dipidana dengan pidana denda paling banyak $\mathrm{Rp}$ 1.000.000.000,00 (satu milliard rupiah).

3) Nakhoda yang mengoperasikan kapal penangkap ikan berbendera asing yang telah memiliki izin penangkapan ikan, yang tidak menyimpan alat penangkapan ikan di dalam palka selama berada di luar daerah penangkapan ikan yang diizinkan di wilayah pengelolaan perikanan Republik Indonesia sebagaimana dimaksud dalam Pasal 38 ayat (3),

${ }^{31}$ Ketentuan Pasal 93 ayat (4) sangat tidak konsisten dengan ketentuan pada Pasal 102 yang menyatakan bahwa: Ketentuan tentang pidana penjara dalam Undang-Undang ini tidak berlaku bagi tindak pidana di bidang perikanan yang terjadi di Wilayah Pengelolaan Perikanan Republik Indonesia sebagaimana dimaksud dalam Pasal 5 ayat (1) huruf b, kecuali telah ada perjanjian antara Pemerintah Republik Indonesia dengan pemerintah negara yang bersangkutan. Intinya ketentuan Pasal 102 ini mengecualikan bagi kapal berbendera asing sebagaimana dimaksud dalam Pasal 5 ayat (1b) terutama Negara Indonesia mempunyai perjanjian dengan negara lain terkait pengelolaan wilayah perikanan. Hal ini berpotensi ketidakadilan dalam penegakannya bagi kapal nasional dan kapal berbendera asing. 
Fakultas Hukum Universitas Komputer Indonesia

Vol. 3 No. 2 Juli 2021

dipidana dengan pidana denda paling banyak Rp500.000.000,00 (lima ratus juta rupiah).

a. Pasal 100 yang menyatakan bahwa: Setiap orang yang melanggar ketentuan yang ditetapkan sebagaimana dimaksud dalam Pasal 7 ayat $(2)^{32}$ dipidana dengan pidana denda paling banyak Rp250.000.000,00 (dua ratus lima puluh juta rupiah).

b. Pasal 100 A yang menyatakan bahwa: Dalam hal tindak pidana sebagaimana dimaksud dalam Pasal $28 \mathrm{~A}^{33}$, pemalsuan persetujuan sebagaimana dimaksud dalam Pasal 35 ayat $(1)^{34}$, dan pemalsuan pendaftaran sebagaimana dimaksud dalam Pasal 36 yang melibatkan pejabat, pidananya ditambah $1 / 3$ (satu pertiga) dari ancaman pidana pokok.

f. Peradilan tindak pidana selain sudah diatur dalam beberapa regulasi, namun Pemerintah Indonesia masih terus mengupayakan untuk menciptakan peradilan tindak pidana ilegal fishing dapat diadili dengan cepat, tepat dalam masa pandemic covid-19 ini, maka dari itu pemerintah menciptakan beberapa regulasi diantaranya:

a. Pertama, Mahkamah Agung menerbitkan Surat Edaran Mahkamah Agung Nomor 1 Tahun 2020 yang diterbitkan tanggal 23 Maret 2020, edaran dimaksud menjadi dasar pijakan bagi lembaga peradilan kaitannya dalam proses penegakan hukum pidana, yang kemudian pada tanggal 26 Maret 2020 Badan Peradilan Umum Mahkamah Agung mengeluarkan Memorandum Nomor 72/DJU/PS.003/2020 terkait sidang pidana secara telekonferensi;

b. Kedua, Kementerian Hukum dan Hak Asasi Manusia menerbitkan Surat Menteri Hukum dan Hak Asasi Manusia kepada Ketua Mahkamah Agung, Jaksa Agung dan Kapolri nomor M.HH.PK.01.01.01-04 tanggal 24 Maret 2020 perihal Penundaan Sementara Pengiriman Tahanan ke Rutan/ Lapas di Lingkungan Kementerian Hukum dan Hak Asasi Manusia sebagai Upaya Pencegahan Penyebaran Covid-19, yang menyampaikan bahwa terhitung mulai tanggal 18 Maret 2020, kegiatan pelayanan kunjungan, penerimaan tahanan baru dan kegiatan sidang ditunda sampai batas waktu yang akan diberitahukan kemudian serta dimohon agar dilakukan penundaan pengiriman tahanan ke Rutan/ Lapas di lingkungan Kemenkumham; dan

c. Ketiga, Kejaksaan Agung mengeluarkan surat yang ditandatangani oleh Jaksa Agung perihal Optimalisasi Pelaksanaan Tugas, Fungsi, dan Kewenangan di tengah Upaya Mencegah Covid-19, yang salah satu poinnya mengupayakan sidang pidana menggunakan video conference/ live streaming. Dan dipertegas dengan dikeluarkan Intruksi Jaksa Agung Nomor 5 tahun 2010 Tentang Kebijakan Pelaksanaan Tugas dan Penanganan Perkara Selama Masa Pencegahan Covid-19 di Lingkungkan Kejaksaan RI. Serta diterbitkan Surat

${ }^{32}$ Pasal 7 ayat (2) menyatakan bahwa: "Setiap orang yang melakukan usaha dan/ atau kegiatan pengelolaan perikanan wajib mematuhi ketentuan sebagaimana dimaksud pada ayat (1) mengenai: a. jenis, jumlah, dan ukuran alat penangkapan ikan; b. jenis, jumlah, ukuran, dan penempatan alat bantu penangkapan ikan; c. daerah, jalur, dan waktu atau musim penangkapan ikan; d. persyaratan atau standar prosedur operasional penangkapan ikan; e. sistem pemantauan kapal perikanan; f. jenis ikan baru yang akan dibudidayakan; g. jenis ikan dan wilayah penebaran kembali serta penangkapan ikan berbasis budi daya; h. pembudidayaan ikan dan perlindungannya; i. pencegahan pencemaran dan kerusakan sumber daya ikan serta lingkungannya; j. ukuran atau berat minimum jenis ikan yang boleh ditangkap; k. kawasan konservasi perairan; 1. wabah dan wilayah wabah penyakit ikan; $\mathrm{m}$. jenis ikan yang dilarang untuk diperdagangkan, dimasukkan, dan dikeluarkan ke dan dari wilayah Negara Republik Indonesia; dan n. jenis ikan yang dilindungi.

${ }^{33}$ Setiap orang dilarang: (a). memalsukan SIUP, SIPI, dan SIKPI; dan/atau (b). menggunakan SIUP, SIPI, dan SIKPI palsu.

34 Setiap orang yang membangun, mengimpor, atau memodifikasi kapal perikanan wajib terlebih dahulu mendapat persetujuan Menteri. 
Fakultas Hukum Universitas Komputer Indonesia

Vol. 3 No. 2 Juli 2021

Jaksa Agung Muda Bidang Pidana Umum (Jampidum) kepada Kepala Kejaksaan Tinggi dan Kepala Kejaksaan Negeri seluruh Indonesia nomor B1271/E/EJP/03/2020 tanggal 24 Maret 2020 perihal Penanganan Perkara Tindak Pidana Umum dalam Masa Tanggap Darurat Covid-19, yang menyampaikan untuk melakukan koordinasi dengan jajaran Kepolisian, Kantor Wilayah Kemenkumham/ Kepala Lembaga Pemasyarakatan (Kalapas) dan Pengadilan Tinggi maupun Pengadilan Negeri untuk melakukan penundaan pelimpahan tersangka dan barang bukti (Tahap II) dan apabila mendesak dalam hal masa tahanan habis, tahap II tetap dapat dilaksanakan dengan ketentuan penyidik bersedia menerima penitipan tahanan tersebut, serta melaksanakan persidangan sesuai jadwal.

Peran pemerintah sangat penting dalam meniadakan, memerangi dan mencegah praktek perikanan ilegal. Ketika pemerintah dapat membuat kebijakan yang tepat, sektor pelaku usaha dan pasar dapat berfungsi dan berperan secara baik dalam mencegah perikanan ilegal. Dalam proses pengawasan kapal perikanan dan penanggulangan kegiatan ilegal fishing salah satu unsur yang tidak dapat dikesampingkan adalah penguatan sarana dan prasarana pengawasan yang tentu saja sangat menunjang kegiatan-kegiatan pengawasan di lapangan. Adapun sarana dan prasarana yang harus diperkuat adalah: ${ }^{35}$

1. Dengan bertambahnya armada-armada patrol diharapkan dapat mengawasi wilayah laut Indonesia yang sangat luas, terutama di daerah-daerah perbatasan yang sangat rentan terhadap kegiatan ilegal fishing.

2. Meningkatkan frekuensi operasional pengawasan kapal patrol.

3. Memperkuat sumber daya manusia dalam bidang pengawasan dengan cara memberikan pelatihan-pelatihan tentang kegiatan pengawasan baik bersifat regional maupun internasional.

4. Mendeteksi kapal asing yang akan memasuki wilayah Indonesia dengan menggunakan Radar, Automatic Identification System (AIS), Vessel Monitoring System (VMS), Global Positioning System (GPS), Peta Laut dll. ${ }^{36}$

5. Melakukan pemeriksaan dokumen, orang, muatan terhadap semua kapal yang dianggap mencurigakan melakukan tindak pidana seperti ilegal fishing.

6. Meningkatkan kerja sama dalam melakukan Pemberantasan Ilegal Fishing baik yang bersifat bilateral, regional dan multilateral maupun dengan instansi terkait dan pemerintah daerah. $^{37}$

7. Memberikan pendampingan dan pelatihan untuk nelayan-nelayan dalam melakukan pengelolaan hasil perikanan serta menjamin keamanan dari gangguan kapal ilegal fishing terhadap nelayan-nelayan Indonesia ketika melakukan kegiatan penangkapan di laut Natuna.

8. Melakukan komunikasi dengan pemerintah pusat khususnya memberikan info kepada Kementerian Luar Negeri dengan format laporan awal seperti kronologis, lokasi, identitas kapal, dugaan tindak pidana, identitas anak buah kapal. ${ }^{38}$

9. Melakukan ratifikasi terhadap beberapa instrumen internasional dan regional seperti ratifikasi Port State of Measures Agreement (PSMA) (Perpres No. 43 Tahun 2016) dan Permen KP No.39 Tahun 2019 tentang Pedoman Pelaksanaan PSMA. ${ }^{39}$

\footnotetext{
35 Bayu Y. Suharto, Johnny Budiman dan Denny B.A. Karwur. "Analisis Pengawasan Kapal Perikanan Terhadap Penanggulangan Ilegal Fishing di Perairan Kabupaten Kepulauan Sangihe Indonesia”, Jurnal Kebijakan Sosial Ekonomi Kelautan Perikanan vol. 7, no. 2 (Desember, 2017): 123. https://garuda.ristekbrin.go.id/journal/view/14025?page=3

${ }^{36}$ Kresna Buntoro,Op.Cit., 17.

${ }^{37}$ Pung Nugroho Saksono, Op.Cit., 22.

${ }^{38}$ Kresna Buntoro.,Op.Cit.,17.

${ }^{39}$ Pung Nugroho Saksono.,Op.Cit., 24.
} 
Fakultas Hukum Universitas Komputer Indonesia

Vol. 3 No. 2 Juli 2021

Selain memperkuat sarana dan prasarana dari dalam maupun eksternal Pemerintah Indonesia dapat menerapkan beberapa langkah dalam melindungi masyarakat seperti: ${ }^{40}$

1. Pelaksanaan pilar keempat dalam upaya mewujudkan visi Indonesia Sebagai Poros Maritim Dunia. Pembangunan Indonesia sebagai Poros Maritim, dilandasi 5 (lima) pilar negara maritim. Pilar keempat didasarkan untuk memperkuat diplomasi maritim; dilakukan dengan cara bersama-sama menghilangkan sumber konflik di laut, seperti pencurian ikan (ilegal fishing), pelanggaran kedaulatan, sengketa wilayah, perompakan, dan pencemaran laut.

2. Upaya untuk menimbulkan efek jera dan atau efek gentar (shock therapy) terhadap pelaku tindak pidana ilegal fishing seperti kebijakan penenggelaman kapal berbendera asing pelaku tindak pidana ilegal fishing, dengan cara membakar, meledakkan serta menenggelamkan kapal berbendera asing pelaku tindak pidana ilegal fishing, kebijakan progresif yang diharapkan dapat menimbulkan efek jera bagi para pelaku ilegal fishing. Kebijakan dan tindakan tegas semacam ini tampak efektif memberikan shock therapy terhadap pelaku, sekaligus mampu mengembalikan kehormatan dan martabat Indonesia atas kedaulatan wilayahnya.

3. Pelaksanaan kebijakan kriminal berupa kebijakan pencegahan dan penanggulangan kejahatan, kebijakan penenggelaman kapal berbendera asing pelaku tindak pidana ilegal fishing, pada dasarnya merupakan bentuk pelaksanaan kebijakan kriminal, yang merupakan bagian dari kebijakan sosial pemerintah Indonesia, yaitu keseluruhan kebijakan yang dilakukan melalui perundang-undangan dan badan-badan resmi, yang bertujuan untuk menegakkan norma-norma sentral dari masyarakat. Kebijakan ini dilakukan dengan didasarkan dan berpedoman pada ketentuan Undang-Undang Nomor 45 Tahun 2009 tentang Perubahan Atas Undang-Undang Nomor 31 Tahun 2004 tentang Perikanan, Pasal 69 ayat (1) jo. Pasal 76A dan ayat (4) jo. Undang-Undang Nomor 8 Tahun 1981 (KUHAP), Pasal 38 jo Pasal 45 dan Pasal 38.

4. Penegasan, perwujudan dan pelaksanaan yurisdiksi dan kedaulatan Negara Indonesia. Kebijakan penenggelaman kapal berbendera asing pelaku tindak pidana ilegal fishing pada dasarnya merupakan penegasan, perwujudan dan pelaksanaan yurisdiksi dan kedaulatan Negara Indonesia. Kebijakan ini tidak hanya untuk menjaga kedaulatan dan menegakan peraturan perundang-undangan sumber daya kelautan dan perikanan Indonesia, tetapi juga sebagai bentuk tanggung- jawab Indonesia dalam menjaga keselamatan dan keamanan dunia kemaritiman internasional.

5. Upaya luar biasa pemberantasan ilegal fishing sebagai kejahatan utama di Laut. Pemerintah Indonesia menyebut tindak pidana ilegal fishing sebagai bentuk kejahatan transnasional terorganisasi (Transnational Organized Crimes-TNC). Selain itu tindak pidana ilegal fishing dikategorikan sebagai kejahatan atau tindak pidana utama di laut, yang disebut sebagai kejahatan yang dapat dibarengi atau menimbulkan kejahatan lainnya. Kejahatan terorganisir yang dimaksud karena dilakukan lebih dari satu negara, dilakukan oleh kelompok kejahatan terorganisir, dan merupakan tindak pidana serius. Ilegal fishing juga dapat menjadi pintu masuk dalam melakukan kejahatan lain, misalnya perdagangan manusia, pelanggaran Hak Asasi Manusia (HAM), penyeludupan narkoba, dan lainnya.

Upaya selanjutnya, menerapkan Peraturan Pemerintah Nomor 37 Tahun 2002 tentang Hak dan Kewajiban Kapal dan Pesawat Udara Asing Dalam Melaksanakan Hak Lintas Alur Laut Kepulauan Melalui Alur Laut Kepulauan. Dalam Peraturan Pemerintah ini dengan tegas diatur jalur-jalur bagi kapal-kapal yang akan melintasi wilayah Indonesia.

\footnotetext{
${ }^{40}$ Desi Yunitasari. "Penegakan Hukum Di Wilayah Laut Indonesia Terhadap Kapal Asing Yang Melakukan Ilegal Fishing Mengacu Pada Konvensi UNCLOS 1982", Jurnal Pendidikan Kewarganegaraan vol.8 no.1 (Februari, 2020): 9. https://ejournal.undiksha.ac.id/index.php/JJPP/article/view/23551.
} 


\section{KESIMPULAN}

Peranan Pemerintah Indonesia dalam menyikapi kasus ilegal fishing dengan melakukan pencegahan dan pengamanan di wilayah Indonesia yang dilandasi dengan menerapkan peraturan internasional maupun peraturan nasional. Indonesia telah menerapkan berbagai regulasi yang terkait dan diharapkan dapat menanggulangi tindakan pencurian ikan (ilegal fishing).

Dalam tataran hukum Indonesia sudah dapat dikatakan memadai, namun dalam pelaksanaannya pada masa pandemi terjadi tren kenaikan ilegal fishing. Sehingga upaya yang harus dilakukan oleh Indonesia sebagai Negara Kepulauan yang tergolong besar dapat menempatkan kapal-kapal penjaga di wilayah perairan Indonesia khususnya di wilayah perbatasan Negara Indonesia dengan Negara lain, seperti Malaysia, Singapura, Timor leste, Palau, Australia dan negaranegara lain yang berbatasan dengan Negara Indonesia.

Dalam hal ini tindakan ilegal fishing berdasarkan data di atas terjadi di wilayah kedaulatan dan di ZEE Indonesia. Artinya pengamanan wilayah laut Indonesia tidak hanya di wilayah perbatasan maritim dengan negara-negara lain, namun juga di wilayah yang rawan terjadinya tindakan ilegal fishing.

Pemerintah Indonesia telah membuat peraturan mengenai hak dan kewajiban kapal asing dalam melakukan pelayaran di wilayah Indonesia yang tertuang dalam Peraturan Pemerintah Nomor 37 Tahun 2002 tentang Hak dan Kewajiban Kapal dan Pesawat Udara Asing Dalam Melaksanakan Hak Lintas Alur Laut Kepulauan Melalui Alur Laut Kepulauan. Dengan adanya aturan ini menjadi lebih jelas hal-hal apa saja yang tidak boleh dan ketetapan apa saja yang boleh dilakukan dalam melaksanakan lintas di perairan Kepulauan Indonesia. Sehingga pemerintah Indonesia dalam rangka mencegah ataupun meminimalisir ilegal fishing dapat menerapkan aturan ini dengan tegas.

\section{DAFTAR PUSTAKA}

Statutory regulations

United Nations Convention on The Law of The Sea 1982.

Undang-Undang Nomor 5 Tahun 1983 tentang Zona Ekonomi Eksklusif Indonesia (UU 5/1999).

Undang-Undang Nomor 17 Tahun 1985 tentang Pengesahan United Nations Convention on the Law of the Sea 1982 (UU 17/1985).

Peraturan Menteri Kelautan dan Perikanan Nomor PER/01/MEN/2009 tentang Wilayah Pengelolaan

\section{A. Books} Perikanan Republik Indonesia (Permen KKP 01/2009).

Armen, Zulham, dkk. Rekomendasi Pengembangan Perikanan Tangkap di Natuna dan Sekitarnya. Jakarta: PT Raja Grafindo Persada, 2017.

Mahmuda, Nunung. Ilegal Fishing-Pertanggungjawaban Pidana Korporasi di Wilayah Perairan Indonesia. Jakarta: PT Sinar Grafika, 2015.

Marlina dan Faisal. Aspek Hukum Peran Masyarakat dalam Mencegah Tindak Pidana Perikanan. Jakarta: Sofmedia, 2013.

\section{Journal Articles}

Maryani, Halimatul dan Adawiyah Nasution. "Rekosepsi Model Pemberantasan Ilegal Fishing di Perairan Indonesia: Analisis Perspektif Hukum Internasional." Jurnal Legislasi Indonesia 16, no. 3 (September 2019): 383. https://docplayer.info/169316433-Rekonsepsi-modelpemberantasan-illegal-fishing-di-perairan-indonesia-analisis-perspektif-hukuminternasional.html

Suharto, Bayu Y., Johnny Budiman dan Denny B.A. Karwur. "Analisis Pengawasan Kapal Perikanan Terhadap Penanggulangan Ilegal Fishing di Perairan Kabupaten Kepulauan Sangihe Indonesia." Jurnal Kebijakan Sosial Ekonomi Kelautan Perikanan 7, no. 2 (Desember, 2017): 123. https://garuda.ristekbrin.go.id/journal/view/14025?page=3

Yunitasari, Desi. "Penegakan Hukum Di Wilayah Laut Indonesia Terhadap Kapal Asing Yang Melakukan Ilegal Fishing Mengacu Pada Konvensi UNCLOS 1982.” Jurnal Pendidikan 
Fakultas Hukum Universitas Komputer Indonesia

Vol. 3 No. 2 Juli 2021

Kewarganegaraan

8 no. 1

(Februari,

2020):

9.

\section{Makalah Seminar}

https://ejournal.undiksha.ac.id/index.php/JJPP/article/view/23551

Hasan, Syarief. "Seminar Tentang Sikap Politik Indonesia Terhadap Laut Cina Selatan”, Webinar Asosiasi Dewan Profesor Indonesia, 2020.

Mahabror, Dendy dan Jenjen Jenhar Hidayat. "Analisis Kerugian Ekonomi Akibat Ilegal Fishing di Zona Ekonomi Eksklusif Perairan Natuna", Seminar Nasional Kelautan dan Perikanan V, 2018.

Saksono, Pung Nugroho. "Upaya Indonesia Memerangi IUU Fishing”, Webinar Situasi Keamanan Laut China Selatan di Tengah Pandemi Covid-19 Dalam Perspektif Politik Hukum Internasional serta Sikap Indonesia, 2020.

Saksono, Pung Nugroho. "Tantangan Pengawasan Perikanan di Perbatasan", Webinar Penengakan Hukum di Perairan Perbatasan, 2020. https://www.youtube.com/watch?v=e1bgSyVTL0/diakses/8/10/2020.

Buntoro, Kresna. "Penegakan Hukum di Perbatasan Laut: Legal dan Practical Approach", Webinar Asosiasi Profesor Indonesia, 2020.

\section{Article of a Magazine or Newspaper}

Dahuri, Rokhmin. "Selamatkan Indonesia dari Ilegal Fishing”, Majalah Samudera, Mei 2012. http://rokhmindahuri.info/2012/10/04/selamatkan-indonesia-dari-iuu-fishing/

Legianto, Bayu. "Hasil Operasi Kapal Pengawas Perikanan KKP”, suarakarya.co.id, Juli 2019. https://suarakarya.co.id/kinerja-pemerintah-kkp-tangkap-67-kapal-pencuriikan/15703/diakses/8/10/2020

Sofuroh, Faidah Umu. "2 Kapal Asing Ilegal Vietnam Ditangkap di Laut Natuna Utara", DetikNews.com, April 4, 2020. https://news.detik.com/berita/d-4965402/2-kapal-asingilegal-vietnam-ditangkap-di-laut-natuna-utara

\section{Internet}

Pregiwati, Lily Aprilya. "Kinerja Pengawasan KKP Sepanjang Triwulan 1/2019 Tunjukkan Capaian Positif." kkp.go.id. https://kkp.go.id/artikel/10031-kinerja-pengawasan-kkp-sepanjangtriwulan-1-2019-tunjukkan-capaian-positif/diakses/8/10/2020 (accessed October 8, 2020).

Maronie, Sherief dan Rangga Dwi Wahyuputra. "Penanganan Tindak Pidana Perikanan Oleh PPNS Perikanan di Masa Pandemi Covid-19.” kkp.go.id. https://kkp.go.id/djpsdkp/artikel/19429penanganan-tindak-pidana-perikanan-oleh-ppns-perikanan-di-masa-pandemi-covid-19 (accessed May 12,2020).

Yunanda, Trian. “Arah Kebijakan Pengelolaan Sumber daya Perikanan Tahun 2020-2024.” kkp.go.id Slide 1 (kkp.go.id) (accessed April 4, 2020). 